\title{
The Protective Effects of Acetyl L-Carnitine on Testis Gonadotoxicity Induced by Cisplatin in Rats
}

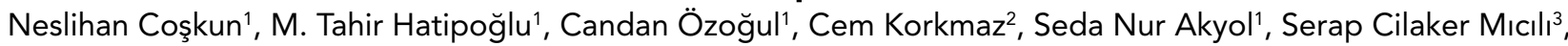
Gülistan Sanem Arık', Deniz Erdoğan

${ }^{1}$ Department of Histology and Embriyology, Gazi University School of Medicine, Ankara, Turkey

${ }^{2}$ IVF Laboratories, Gülhane Military Medical Academy, Ankara, Turkey

${ }^{3}$ Department of Histology and Embriyology, Dokuz Eylul University School of Medicine, Izmir, Turkey

\begin{abstract}
Background: Cisplatin, an effective antineoplastic agent, damages normal cells in a manner related to chemotherapy. Acetyl L-carnitine protects cells against mitochondrial and nuclear damage induced by chemotherapy.

Aims: Animal experiment

Study Design: The aim of this study was to examine the protective effects of acetyl L-carnitine on cisplatin-induced gonadotoxicity in testicular structures. Twenty-four male Wistar albino rats were divided into four Groups $(n=6)$ : Group 1 (control) was administered saline; Group 2 was administered acetyl Lcarnitine; Group 3 was administered cisplatin; and Group 4 was pre-treated with acetyl L-carnitine before cisplatin administration.
\end{abstract}

Methods: After $72 \mathrm{hr}$ of treatment with cisplatin, the rats were sacrificed, and the testicular tissues were removed. Morphometric, histomorphologic and immunohistochemical analyses were conducted.

Results: At the end of the experiment, Group 3 was characterised by statistically significant weight loss, a degenerative appearance of the seminiferous tubules in the peripheral region, separation of spermatogenic cell series from the tubular wall, cellular debris in the lumen and central interstitial oedema. Sperm morphology appeared to be abnormal. Tubular diameter and wall thickness decreased, and the number of TUNEL- and active caspase-positive cells increased compared with the other Groups. The histological findings in Group 4 were better than those in Group 3.

Conclusion: It was concluded that the prophylactic use of acetyl L-carnitine protects against cisplatin-induced testicular tissue damage.

Key Words: Acetyl L-carnitine, cisplatin, gonadotoxicity, testis

Received: 19.07.2012

Accepted: 14.02 .2013

\section{Introduction}

The use of antineoplastic agents in cancer treatments has toxic effects on all rapidly growing healthy cells, such as those of the gastrointestinal system, hematopoietic system and reproductive system cells, in addition to tumour tissues (1-3).

Cisplatin induces cytotoxicity in healthy tissues by contributing to the production of reactive oxygen species, inducing mitochondrial oxidative damage and apoptosis, inhibiting antioxidant enzymes and releasing free radicals. Gonadotoxicity is one of the most important dose-limiting side effects (4-7). It directly affects the spermatogonia, inhibiting spermatogenesis or impairing the cellular functions of Sertoli cells, which leads to permanent infertility (8-10). Therefore, it has become important to supplement with antioxidants to reduce the damage created by anti-tumoural drugs (11).

L-carnitine was previously identified as a powerful antioxidant and free radical scavenger $(12,13)$. The potent anti-apoptotic ability of acetyl L-carnitine to prevent oxidative stress-related mitochondrial damage and subsequent mitochondria-dependent apoptosis has been demonstrat- ed in many cell types (14-17). The high concentration of acetyl L-carnitine that is present in testicular tissues leads to an increase in mitochondrial fatty acid oxidation, which is used to produce energy for sperm respiration and motility (18-20).

Experimental studies have reported that germ cell apoptosis is induced by treatment with cisplatin (9). The anti-apoptotic effect(s) of carnitine in the testes may also contribute to this apoptosis, but such an effect remains speculative and requires further investigation. Therefore, the present study was undertaken to investigate the protective role of acetyl L-carnitine on cisplatin-induced testicular damage. Histopathological and immunohistochemical examination with a light microscope were used to investigate the mechanisms of cisplatin-induced testicular apoptosis, including its activation of apoptotic pathways.

\section{Material and Methods}

\section{Animals and Experimental Design}

Twenty-four adult male Wistar albino rats weighing 200$250 \mathrm{~g}$ were obtained from the Laboratory Animal Breeding 
and Experimental Research Centre of Gazi University (GUDAM). The animals were housed under standard laboratory conditions $\left(12 \mathrm{hr}\right.$ light/dark cycle, $20 \pm 2^{\circ} \mathrm{C}$, relative humidity $50 \pm 15 \%)$ for three days. Standard food pellets and tap water were available ad libitum. The experimental protocol was approved by the Ethical Committee of Gazi University.

The rats were divided into four Groups: Group $1(n=6)$ (control) was given saline; Group $2(n=6)$ was treated with acetyl L-carnitine; Group $3(n=6)$ was treated with cisplatin; and Group $4(n=6)$ was pre-treated with acetyl L-carnitine before cisplatin treatment. The actual experimental findings, however, were interpreted using only 23 rats because one rat from Group 3 died during the experimental process.

Acetyl L-carnitine $\left(\right.$ Sigma $^{\circledR},{ }$, Germany, $200 \mathrm{mg} / \mathrm{kg}$ body weight, $600 \mathrm{mg}$ dissolved in $3 \mathrm{~mL}$ of saline solution) was injected subcutaneously (s.c.) into the rats in Groups 2 and 4. Saline was simultaneously injected s.c. at the same dose in Groups 1 and 3. Cisplatin (Cisplatin-Ebewe ${ }^{\circledR} 13 \mathrm{mg} / \mathrm{kg}$ body weight, Liba, Istanbul, Turkey) was administered $30 \mathrm{~min}$ after acetyl L-carnitine/saline injection via intraperitoneal infusion for $1 \mathrm{hr}$ only on the first day in Groups 3 and $4(15,16)$.

Rats were sacrificed $72 \mathrm{hr}$ after cisplatin treatment (the fourth day) using anaesthesia with ketamine hydrochloride (40 $\mathrm{mg} / \mathrm{kg}$ ) (Ketalar, Eczacibasi, Istanbul, Turkey) and xylazine hydrochloride (5 mg/kg) (Rompun, Bayer, Istanbul, Turkey). After sacrificing, the testicular tissues of the rats were removed.

\section{Histological and Morphometric Investigations}

The testes were fixed in $10 \%$ neutral buffered formalin and embedded in paraffin after routine histological procedures were performed. Then, $4 \mu \mathrm{m}$ sections were obtained from each paraffin block and stained with haematoxylin and eosin (H\&E). Histological analysis was performed using a light microscope (Leica DM 4000, Germany). Seminiferous tubule diameter and wall thickness were measured using the same microscope and a computer-supported imaging system. Measurements of tubular walls were performed in 10 randomly selected areas in six cross-sections for each Group, and the results were compared.

\section{Testicular Sperm Extraction}

Left testicular tissues collected from each Group were placed in dishes containing fertilisation medium (G-IVFTM PLUS) for the testicular sperm extraction (TESE) method, and the tissues were divided into pieces using insulin injector tips. The fertilisation medium including the sperm was then transferred to gradient medium ( $1 \mathrm{~mL}$ of G-IVFTM PLUS medium and ISOLATE 9,7 and $3 \mathrm{~mL}$ aliquots of the medium were used to prepare the 90,70 and $30 \%$ gradients, respectively). These tubes were centrifuged at $1300 \mathrm{rpm}$ for $10 \mathrm{~min}$. Sperm that precipitated to the bottom were re-centrifuged twice at $1300 \mathrm{rpm}$ in the fertilisation medium to remove the gradient medium. After rinsing, sperm that precipitated were spread onto a slide and stained by the KRUGER method, and their morphology was determined.

\section{TUNEL Assay}

The terminal deoxynucleotidyl transferase dUTP nick endlabelling (TUNEL) method was used to assess DNA fragmenta- tion in the cells. Cross-sections obtained from the $4 \mu \mathrm{m}$-thick testicular tissue blocks were incubated at $61^{\circ} \mathrm{C}$. After deparaffinisation, the cross-sections were rinsed with distilled water. Tissues removed from water were incubated with $20 \mu \mathrm{g} / \mathrm{mL}$ proteinase $\mathrm{K}$ (Roche Diagnostics, $\mathrm{GmbH}$ ) at $37^{\circ} \mathrm{C}$ for $25 \mathrm{~min}$ and rinsed with phosphate buffer saline (PBS). Any endogenous peroxidase activity was blocked by incubating in $3 \%$ hydrogen peroxide (Lab Vision, Fremont, USA) for $15 \mathrm{~min}$. The cross-sections were then rinsed with PBS and incubated with the TUNEL kit ( $450 \mu \mathrm{L}$ label solution, $50 \mu \mathrm{L}$ enzyme solution) (Roche, In Situ Cell Death Detection Kit) for $60 \mathrm{~min}$ at $37^{\circ} \mathrm{C}$ in a humid and dark environment and then rinsed with PBS. The cross-sections were then incubated with converter POD (Roche Diagnostics, Indianapolis, USA) solution in a humid environment at $37^{\circ} \mathrm{C}$ for $30 \mathrm{~min}$ and rinsed with PBS. Subsequent staining with diaminobenzidine substrate solution (DAB) was used to determine TUNEL-positive cells. Mayer's haematoxylin was used as a background stain. The sections were placed in xylol for $20 \mathrm{~min}$, after which they were coated with entallan. Cross-sections were evaluated under a light microscope (Leica DM 4000 Germany) using a computer-supported imaging system to take photos using the Leica $Q$ Vin 3 program.

\section{Immunohistochemical Procedure}

The avidin-biotin peroxidase method was used for the immunohistochemical studies to investigate anti-caspase-3, -8 and -9 activities. Four micron-thick cross-sections prepared from testicular tissue blocks were incubated at $61^{\circ} \mathrm{C}$. The tissues were deparaffinised by rinsing with sequential xylol and alcohol solutions, and distilled water was used to remove the alcohol from the dehydrated tissues. To expose receptor areas within the tissue that were blocked by formaldehyde, tissues were exposed to citrate buffer ( $\mathrm{pH}$ 6.0) (Lab Vision, Fremont, USA) under a high temperature. Following the antigen retrieval procedure, the tissues were allowed to cool down at room temperature for $20 \mathrm{~min}$ and then rinsed with distilled water to remove the citrate. Tissues were rinsed with PBS three times for $3 \mathrm{~min}$ each, exposed to $3 \%$ hydrogen peroxide (Lab Vision, Fremont, USA) for $15 \mathrm{~min}$ to block endogenous peroxidase activity and subsequently rinsed with PBS. Ultra V block (Lab Vision, Thermo Scientific) was applied for 5 min to prevent nonspecific binding. Following the blocking stage, sections were kept at room temperature for $45 \mathrm{~min}$ without being washed and exposed to anti-caspase-9 antibody (caspase-9 Ab-4), anti-cleaved caspase- 3 antibody (caspase 3 (CPP32) Ab-4) and primer antibodies that were diluted 1:100. An anti-caspase-8 primer antibody was incubated overnight at $+4^{\circ} \mathrm{C}$. Procedures were resumed the next day. The tissues were rinsed with PBS following the primer antibody, and a secondary antibody (Lab Vision, Thermo Scientific) was applied for $10 \mathrm{~min}$. The tissues were then rinsed with PBS, exposed to a streptavidin peroxidase enzyme (Lab Vision, Thermo Scientific) complex for 10 min and again rinsed with PBS. Lastly, DAB (Spring Bioscience) was added to the medium for approximately 5-10 min to ensure an immune reaction. Mayer's haematoxylin was used as a background stain. The slides were then rinsed using serial alcohol solutions of diminishing concentrations. They were exposed to xylol for $20 \mathrm{~min}$ and were coated with entallan. 
Cross-sections were evaluated under a light microscope (Leica DM 4000 Germany) using a computer-supported imaging system to take images with the Leica $\mathrm{Q}$ Vin 3 program.

\section{Statistical analyses}

All statistical analyses were performed using SPSS statistical software (SPSS for windows, version 11.0). All data were expressed as the mean $\pm \mathrm{SD}$. The differences between rat weights measured at baseline and at the end of the experiment were statistically evaluated using the Wilcoxon signed rank test. Seminiferous tubule diameters and tubular wall thickness were measured in six cross-sections from each Group. TUNEL-positive and caspase-3-, -8- and -9-immunreactive cells were counted out of 100 cells in 10 randomly selected areas on tubular walls in six cross-sections from each Group. Data obtained from the counts in binary Groups were evaluated using the Mann Whitney $U$ test; $p$ values less than 0.05 were accepted as statistically significant.

\section{Results}

\section{Statistical Assessment of the Body Weights}

Total average body weights of the rats were measured at baseline and upon completion of the experiment. The weights at baseline were $235.50 \pm 11.05 \mathrm{~g}$ in Group 1; 239.00 \pm 3.16

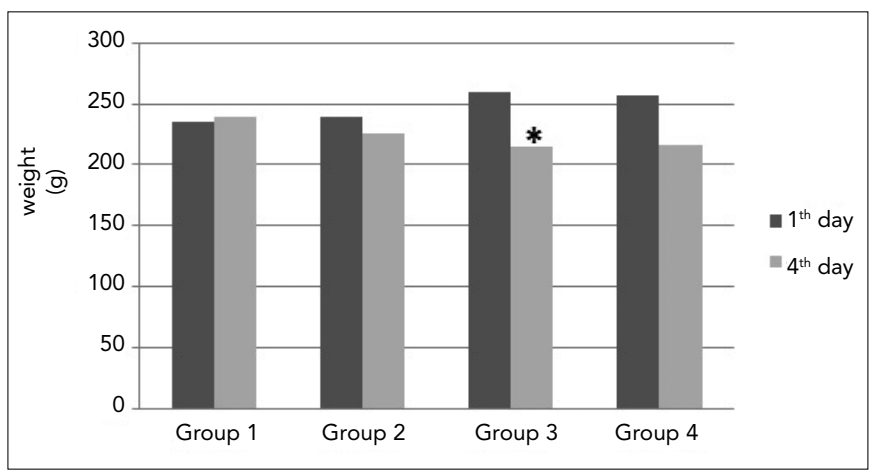

Figure 1. Weights of the rats in each Group at baseline and upon completion of the experiment. (* weight loss was statistically significant in Group 3 compared with the other Groups, p<0.05)

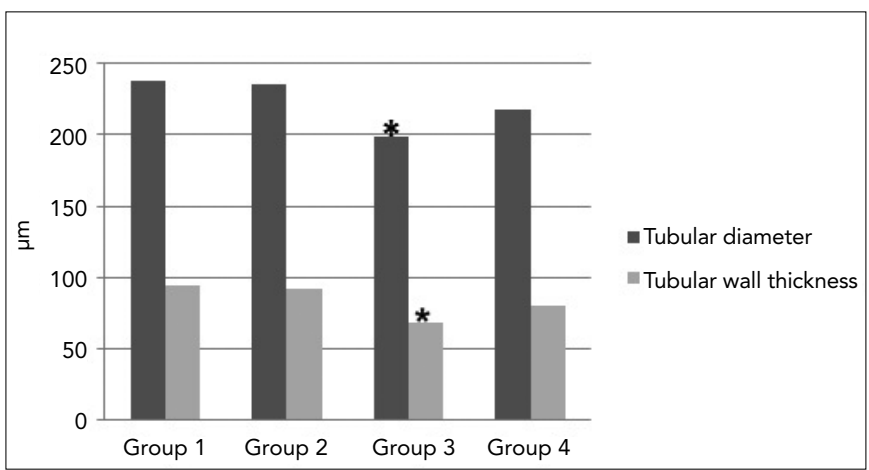

Figure 2. Measurements of tubular diameter and wall thickness. (* tubular diameter and wall thickness were significantly less in Group 3 compared with the other Groups, $\mathbf{p}<0.05$ ) $\mathrm{g}$ in Group 2; $259.60 \pm 4.50 \mathrm{~g}$ in Group 3; and 257.33 \pm 5.31 $\mathrm{g}$ in Group 4. Weights at the end of the experiment were $239.66 \pm 10.94 \mathrm{~g}$ in Group 1; 226.16 $\pm 4.70 \mathrm{~g}$ in Group 2; $214.20 \pm 9.09 \mathrm{~g}$ in Group 3; and 216.50 $\pm 6.89 \mathrm{~g}$ in Group 4 (Figure 1). While the difference between the body weights at baseline and completion of the experiment were less significant in Group 1 ( $p=0.046)$, the loss in weight at the completion of the experiment was statistically significant in Groups 2 $(p=0.027), 3(p=0.041)$ and $4(p=0.027)$ compared with baseline. It was observed that weight loss was significantly greater $(p<0.05)$ in rats that experience cisplatin-induced gonadotoxicity compared with those from the other Groups.

\section{Evaluation of Tubular Diameter and Tubular Wall Thick-} ness

The mean seminiferous tubular diameters were $237.8 \pm 28.50$ $\mu \mathrm{m}$ in Group $1 ; 236.1 \pm 29 \mu \mathrm{m}$ in Group 2; $198.6 \pm 28.40 \mu \mathrm{m}$ in Group 3; and $217.8 \pm 26.40 \mu \mathrm{m}$ in Group 4. The mean values of tubular wall thicknesses were as follows: $94.2 \pm 16.6 \mu \mathrm{m}$ in Group 1; 91.4 $\pm 13.7 \mu \mathrm{m}$ in Group 2; 68.2 $\pm 21.20 \mu \mathrm{m}$ in Group 3; 79.8 $\pm 12.8 \mu \mathrm{m}$ in Group 4 (Figure 2). While no significant differences were observed between Groups 1 and $2(p=0.755)$ regarding tubular diameter $(p>0.05)$, the tubular diameters in Group 3 were significantly lower compared with Groups 1 $(p=0.000), 2(p=0.000)$ and $4(p=0.000)$. Tubular diameters in Group 4 were greater compared with Group $3(p=0.000)$ and lower compared with Groups $1(p=0.000)$ and $2(p=0.000)$.

Additionally, there were no significant differences between Group 1 and Group 2 in tubular wall thickness $(p=0.310)$. The tubular wall thickness in Group 3 was significantly lower than in Groups $1(p=0.000), 2(p=0.000)$ and $4(p=0.015)$. The tubular wall thickness in Group 4 was greater than in Group 3 $(p=0.015)$ and lower than in Group $1(p=0.000)$ and Group 2 $(p=0.001)$.

\section{Histomorphologic Findings}

In the tissue cross-sections prepared from samples taken from Group 1, the histological characteristics of the testis were normal (Figure 3a). When testicular tissues from Group 2 were histomorphologically evaluated, they were found to be similar to Group 1 (Figure 3b). Degenerative alterations in the peripheral region of seminiferous tubules, separation of spermatogenic cell series from the seminiferous epithelium, cellular debris in the lumen and central interstitial oedema were observed in sections from Group 3 (Figures 3c-3e). The findings of Group 4 tissues were similar to those of Groups 1 and 2 (Figure 3f).

Normal sperm morphologies were observed in the TESE material obtained from Groups 1, 2 and 4 (Figures 4a, 4b, 4g and $4 \mathrm{~h}$ ). In contrast, Group 3 was characterized by numerous sperm with bent heads and mid-piece anomalies, looping mid-pieces, lasso-like morphologies and sperm with cytoplasmic droplets (Figures 4c-4f).

\section{TUNEL findings}

The number of TUNEL-positive and -negative cells was determined, and the mean values of TUNEL-positive cells were found. Group 1 had $8.84 \pm 1.56$ cells; Group 2 had 


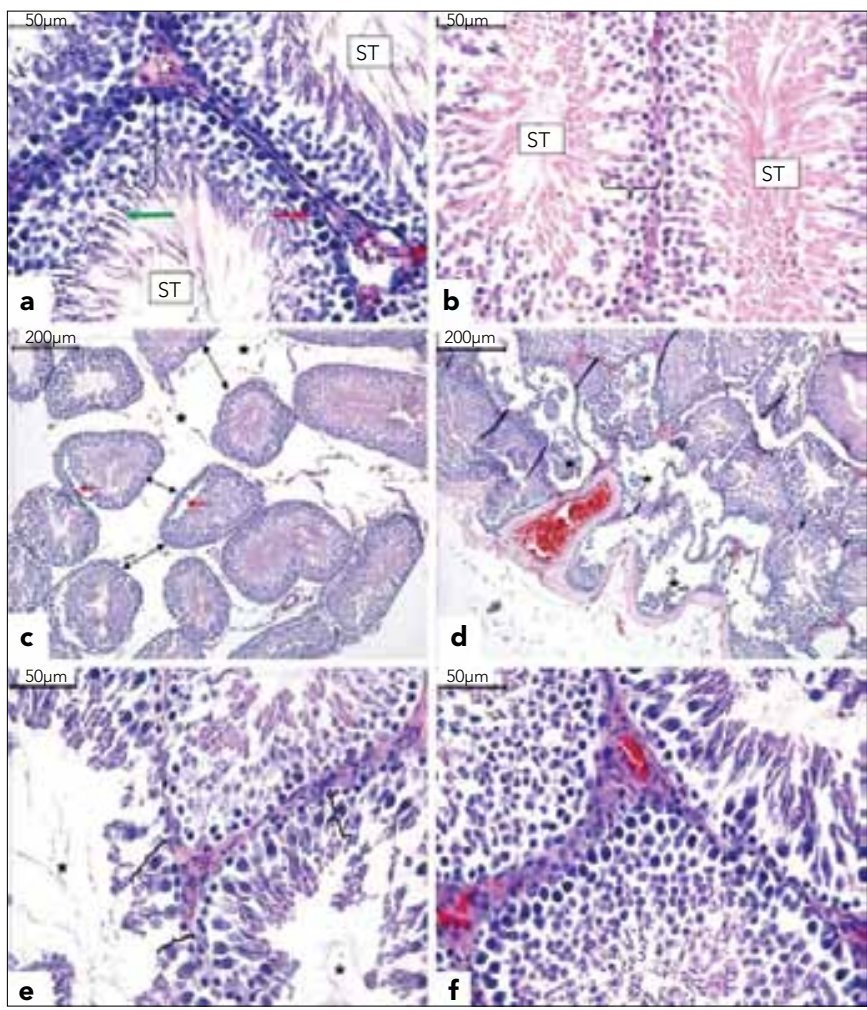

Figure 3. a-f. Normal microscopic appearance of the seminiferous tubules (ST), interstitium (white asterisk), Sertoli cells (red arrow), differentiated germ cells (bracket) and round spermatids (green arrow) in Groups 1 (a) and 2 (b). In Group 3, the seminiferous tubules show interstitial oedema (asterisk), and due to the decrease in tubule diameters, the tubules moved away from one another (black arrows). There is separation of the spermatogenic cell series from the tubular wall (red arrows) (c). Seminiferous tubules show severe degeneration and desquamation of germ cells in the peripheral region (asterisk) (d), reduction in the germinal cell layer of seminiferous tubules (bracket) and enlargement of the lumen (asterisk) (e). Group 4 was similar to Groups 1 and 2 (f). (H\&E)

9.4 \pm 2.17 cells; Group 3 had $20.10 \pm 4.47$ cells; and Group 4 had $13.50 \pm 2.77$ cells (Figure 5). TUNEL-positive cell numbers were significantly highest in Group $3(p<0.05)$ compared with Groups $1(p=0.000), 2(p=0.000)$ and $4(p=0.000)$. The mean number of cells displaying DNA fragmentation in Group 4 was higher compared with Groups $1(p=0.000)$ and $2(p=0.000)$ and lower compared with Group $3(p=0.000)$. When compared with Groups 1 and 2, however, they were not statistically significant $(p=0.360)$ (see Figure 6).

\section{Immunohistochemical findings}

The average number of cells expressing caspase-9 was $17.90 \pm 1.79$ in Group 1; $24.79 \pm 1.91$ in Group 2; $37.61 \pm 2.21$ in Group 3; and 20.68 \pm 1.60 in Group 4 (Figure 5). While caspase- 9 activity was statistically significant $(p<0.05)$ in all Groups, it was highest in Group 3 compared with Group 1, 2 or $4(p=0.000)$. Group 4 was significantly different from Groups $1(p=0.000)$ and $2(p=0.000)$. The mean number of caspase-9-positive cells was, however, equivalent to Groups

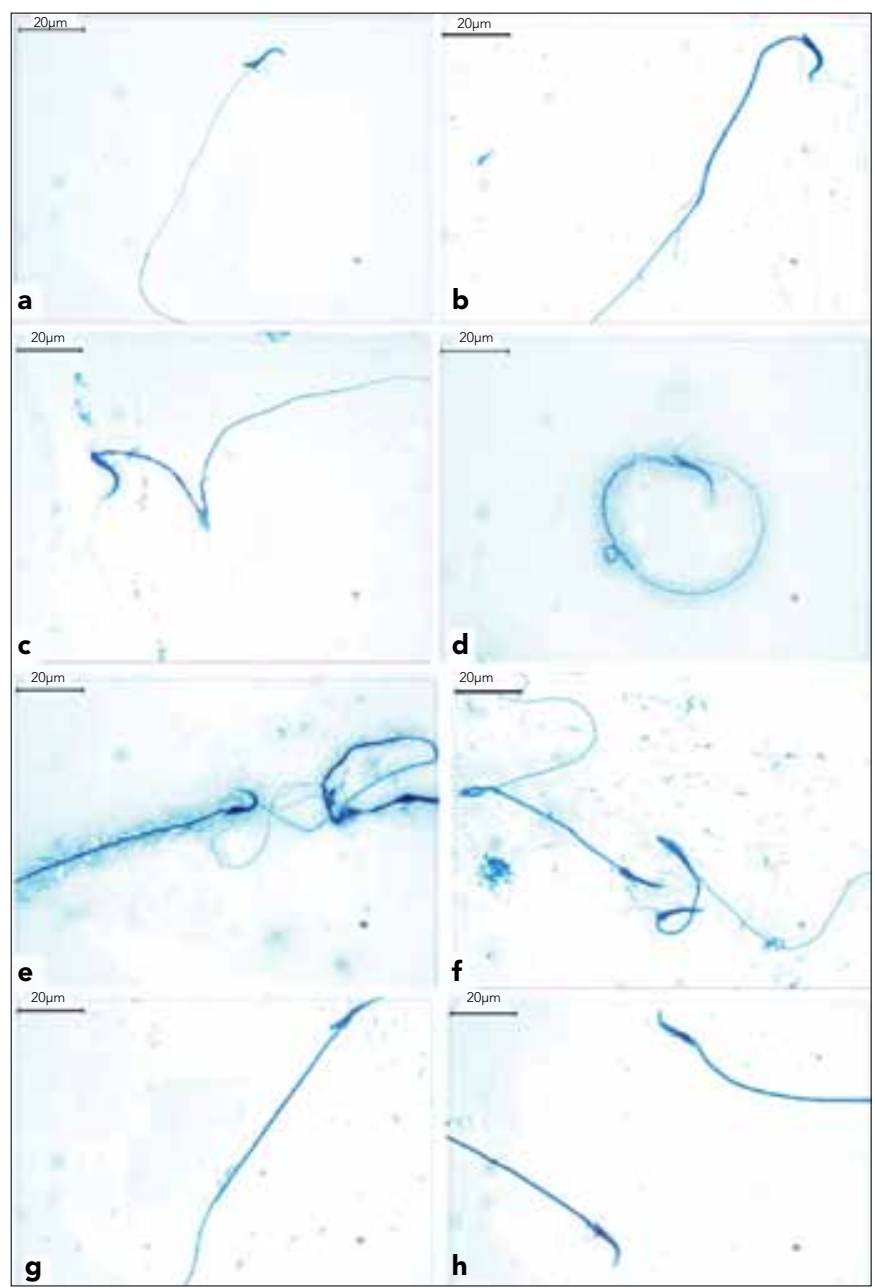

Figure 4. a-h. Normal sperm morphology was observed in TESE materials from Groups 1, 2 and 4 (a, b, g and h). Sperm with bent heads (c), lasso-like sperm (d), midpeace anomalies (e) and looping midpeace sperm (f) were observed in Group 3.

1 and 2, but was lower compared to Group $3(p=0.000)$ (see Figure 6).

The average amount of caspase-8-immunoreactivity in the seminiferous tubule epithelium was $5.2 \pm 0.63$ in Group 1; $5.1 \pm 0.78$ in Group 2; $13.30 \pm 19.1$ in Group 3; and 8.40 9.84 in Group 4 (Figure 5). Caspase-8 activity was highest in Group 3 , while the mean number of caspase-8-positive cells in Group $4(p=0.000)$ was higher compared with Groups $1(p=0.000)$ and $2(p=0.000)$ and lower compared with Group $3(p=0.021)$. When compared with Groups 1 and 2, however, these values were not statistically significant $(p=0.343)$ (see Figure 6).

The mean number of cells that were immunoreactive for caspase-3 was $4.11 \pm 0.73$ in Group 1; $5.5 \pm 1.07$ in Group 2; $10.7 \pm 1.77$ in Group 3; and 6.1 \pm 0.89 in Group 4 (Figure 5). Caspase- 3 activity was highest in Group 3 compared with Groups 1,2 or $4(p=0.000)$. The mean number of caspase-3-positive cells in Group 4 was statistically significant compared with Groups $1(p=0.000)$ and $2(p=0.000)$. However, the mean number of caspase-3-positive cells was similar to Groups 1 and 2 but lower compared with Group $3(p=0.000)$ (Figure 6). 


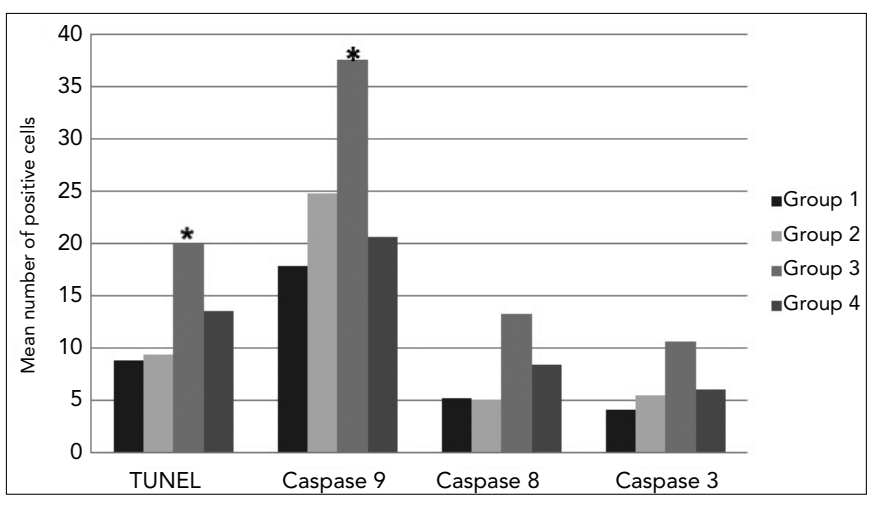

Figure 5. The mean number of TUNEL and caspase-9-, -8and -3-positive cells. (* mean number of TUNEL-positive and caspase-9-immunopositive cells were significantly higher in Group 3 compared with the other Groups, p<0.05)

\section{Discussion}

Cisplatin, which is an antineoplastic agent, was introduced for clinical use after being approved by the American Food and Drug Administration in 1978 (4). Cisplatin is frequently used to treat ovarian, testicular, lung and liver solid tumours. Due to the structural similarity between normal cells and tumour cells, chemotherapeutic drugs, such as cisplatin, cause damage to normal cells in a manner similar to that caused by chemotherapy. However, the powerful anti-tumoural activity of cisplatin also stops the growth and proliferation of cancer cells. Common adverse effects, such as gonadotoxicity, nephrotoxicity, ototoxicity and neurotoxicity, have been reported as dose-limiting adverse effects $(5,15,16)$. After entering a tumour cell, cisplatin activates many signalling pathways to cause apoptosis, necrosis, oxidative stress, fibrogenesis, inflammation, hypoxia and mitochondrial damage, and it also induces cytotoxic effects in healthy cells $(7,10,21-23)$. Moreover, Zhang et al. (9) demonstrated that apoptosis was induced in male germ cells in a dose-dependent fashion following cisplatin administration in Balb/c mice. These authors also observed that the maturity period for cells in the spermatogenetic series decreased, that spermatogenesis was reduced and that fertility was affected.

Acetyl L-carnitine has been shown to protect cells against mitochondrial and free radical-related nuclear DNA damage and to improve mitochondrial functions by reducing stress-mediated DNA damage through reducing the production of oxidants and enhancing antioxidant status (13, 14-17). Many studies have demonstrated that free carnitine levels in the epididymis affect the number, motility and maturity of spermatozoa $(18,19)$.

Topcu et al. (24) stated that administration of gamma radiation caused irregularities in and reduced the number of germ cells, as evidenced by morphological analyses, the pausing of spermatogenesis and vacuolisation in the germinal epithelium. In contrast, administration of L-carnitine alleviated the reduction in germ cell numbers and morphological damage in testicular tissues and exhibited protective effects against the damage caused by radiotherapy.

We examined the effects of cisplatin on testicular tissues and sperm structures using histomorphologic, morphomet-

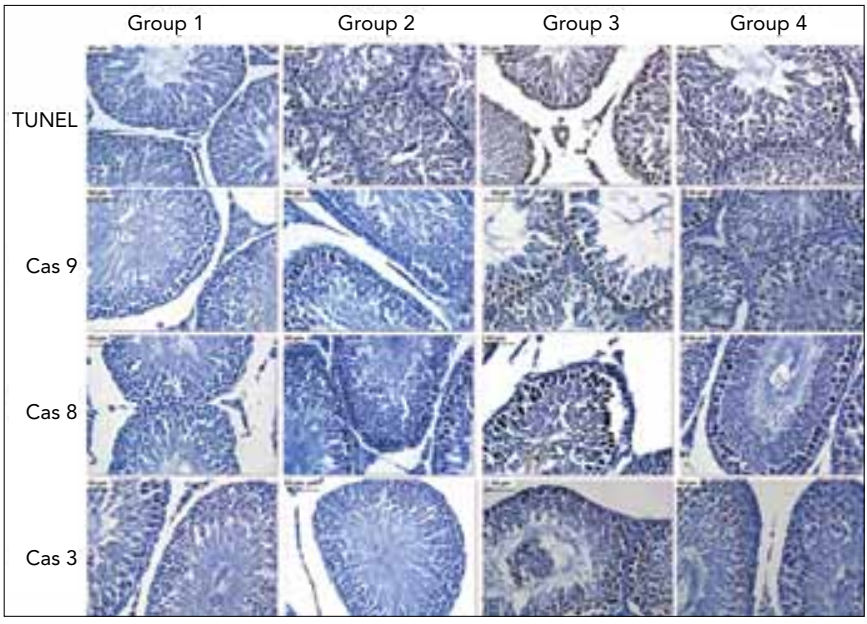

Figure 6. Apoptotic and immunohistochemical findings of all Groups. TUNEL: apoptotic cell death by TUNEL, Cas 3: caspase-3, Cas 8: caspase-8, Cas 9: caspase-9. (DAB, haematoxylin)

ric and apoptotic analyses. Our results suggest that cisplatin treatment induces central interstitial oedema, spermatogenetic cells to part from the tubular walls and cellular debris to accumulate in the lumen of some tubules. When the sperm morphologies were examined with TESE, many sperm were observed with bent heads, mid-piece anomalies, looping midpieces, lasso-like shapes and cytoplasmic droplets (25). The histomorphologic findings in the acetyl L-carnitine+cisplatin pre-treatment Groups were similar to those observed in Groups 1 and 2.

Recently, Favareto et al. (26) assessed the effects of cisplatin treatment and the reversibility of these effects in Wistar albino male rats. After cisplatin treatment, the production of sperm and spermatogenic cell series were decreased, as were tubular diameter, intratesticular testosterone and fertility potential. Consistent with the literature, the morphometric evaluation of seminiferous tubule diameter and tubular wall thickness in the cisplatin treatment Group revealed that they were significantly smaller compared with Groups 1, 2 and 4. In addition, the acetyl L-carnitine+cisplatin pre-treatment Group had greater values compared with the cisplatin treatment Group.

Atessahin et al. (27) concluded that the toxic effects induced by cisplatin administration include a decrease in sperm concentrations, a reduction in sperm motility, an increase in abnormal sperm ratios, a thinning of the seminiferous epithelium, a decrease in the number of seminiferous tubules, an accumulation of germinal cellular debris, oedema in the interstitial area, an increase in lipid peroxidation and a decrease in glutathione peroxidase (GSH-Px) activity. The same authors concluded that following melatonin administration, the GSH-Px antioxidant defence system was enhanced and protective against reactive oxygen radicals, the number of abnormal sperm was reduced, sperm motility and epididymal sperm concentrations were increased and interstitial oedema was reduced. These results were similar to those obtained in our study.

Moreover, Lirdi et al. (28) reported that amifostin protected rats that were administered cisplatin by reducing the num- 
ber of germinal cells with abnormal nuclear morphology (as evaluated by the TUNEL method) and the number of TUNELpositive spermatogonia and primary spermatocytes. At the completion of cisplatin therapy, the number of TUNEL-positive seminiferous tubules and immotile sperm was increased compared with the control Group (26). This result was confirmed in our study, in which the increased number of TUNELpositive cells in tubular walls of the cisplatin Group indicated that cisplatin induces apoptosis in the testicular germ cells. Moreover, acetyl L-carnitine+cisplatin pre-treatment prevented DNA fragmentation.

We also investigated the mechanisms of cisplatin-induced testicular apoptosis, which included an examination of apoptotic pathways induced by caspases-3, -8 and -9 . We found that in the cisplatin Group, the average number of cells labelled for caspases- 8 and -9 were significantly different compared with the other Groups. These findings suggest that cisplatin triggers apoptosis through caspases- 8 and -9 and that pre-treatment prevents apoptosis via the extrinsic and intrinsic pathways. The significantly lower values of caspase-8 activity in the cisplatin Group compared with caspase-9 suggest that testicular apoptosis induced by cisplatin is primarily triggered by intrinsic factors through caspase-9. These results indicate that cisplatin administration initiates the apoptotic process by activating procaspase- 3 and that apoptosis occurs via both the intrinsic and extrinsic paths. The intrinsic pathway, however, was more effective.

High rat mortality rates due to the toxic effects of cisplatin limited our study. Additionally, ultrastructural analyses of testicular tissues were limited due to budgetary reasons.

Studies related to protecting gonads for cancer patients undergoing chemotherapy are ongoing. Currently, sperm or testicular biopsy samples are frozen before chemotherapy treatments are given to male cancer patients. Our study utilised histomorphologic, morphometric and apoptotic parameters to demonstrate that cisplatin caused damage to testicular tissues and sperm morphology and that these damages were alleviated by pre-treating with acetyl L-carnitine. The results of this study indicated that the prophylactic use of acetyl Lcarnitine can be recommended to protect testicular tissue in male patients after chemotherapy treatment.

Ethics Committee Approval: Ethics committee approval was received for this study from the ethical committee of Gazi University.

\section{Informed Consent: N/A}

Peer-review: Externally peer-reviewed.

Author contributions: Concept - C.Ö.; Design - C.Ö., N.C.; Supervision - C.Ö., C.K.; Resource - M.T.; Materials - C.Ö.; Data Collection\&/or Processing - D.E., N.C., G.S.M, S.N.A.; Analysis\&/or Interpretation - S.C.M., N.C., G.S.A.; Literature Search - N.C., G.S.M, S.N. A.; Writing - C.Ö., N.C., S.N.A., G.S.A.; Critical Reviews - C.Ö., N.C, C.K.

Conflict of Interest: No conflict of interest was declared by the authors.

Financial Disclosure: This study was supported by the Gazi University Scientific Research Project Unit, Ankara, Turkey.

\section{References}

1. Sastry J, Kellie SJ. Severe neurotoxicity, ototoxicity and nephrotoxicity following high-dose cisplatin and amifostine. Pediatr Hematol Oncol 2005;22:441-5. [CrossRef]

2. Beijers AJ, Jongen JL, Vreugdenhil G. Chemotherapy-induced neurotoxicity: the value of neuroprotective strategies. Neth J Med 2012;70:18-25.

3. Dohle GR. Male infertility in cancer patients: review of the literature. Int J Urol 2010;17:327-31. [CrossRef]

4. Jamieson ER, Lippard SJ. Structure, Recognition, and Processing of Cisplatin-DNA Adducts. Chem Rev 1999;99:2467-98. [CrossRef]

5. Siddik ZH. Cisplatin: mode of cytotoxic action and molecular basis of resistance. Oncogene 2003;22:7265-79. [CrossRef]

6. Nozaki Y, Furubo E, Matsuno T, Fukui R, Kizawa K, Kozaki T, et al. Collaborative work on evaluation of ovarian toxicity. 6) Two-or four-week repeated-dose studies and fertility study of cisplatin in female rats. J Toxicol Sci 2009;34 Suppl 1:SP73-81. [CrossRef]

7. Ciftci O, Beytur A, Cakir O, Gurbuz N, Vardi N. Comparison of reproductive toxicity caused by cisplatin and novel platinum- $\mathrm{N}$ heterocyclic carbene complex in male rats. Basic Clin Pharmacol Toxicol 2011;109:328-33. [CrossRef]

8. Boekelheide K. Mechanisms of toxic damage to spermatogenesis. J Natl Cancer Inst Monogr 2005;34:6-8. [CrossRef]

9. Zhang X, Yamamoto N, Soramoto S, Takenaka I. Cisplatin-induced germ cell apoptosis in mouse testes. Arch Androl 2001;46:43-9. [CrossRef]

10. Sawhney P, Giammona CJ, Meistrich ML, Richburg JH. Cisplatininduced long-term failure of spermatogenesis in adult $\mathrm{C} 57 / \mathrm{BI} / 6 \mathrm{~J}$ mice. J Androl 2005;26:136-45.

11. Mohamed J, Wei WL, Husin NN, Alwahaibi NY, Budin SB. Selenium supplementation reduced oxidative stress in diethylnitrosamine-induced hepatocellular carcinoma in rats. Pak J Biol Sci 2011;14:1055-60. [CrossRef]

12. Annadurai $T$, Vigneshwari $S$, Thirukumaran $R$, Thomas PA, Geraldine P. Acetyl-L-carnitine prevents carbon tetrachloride-induced oxidative stress in various tissues of Wistar rats. J Physiol Biochem 2011;67:519-30. [CrossRef]

13. Arockia Rani PJ, Panneerselvam C. Carnitine as a free radical scavenger in aging. Exp Gerontol 2001;36:1713-26. [CrossRef]

14. Cetinkaya A, Bulbuloglu E, Kantarceken B, Ciralik H, Kurutas EB, Buyukbese MA, et al. Effects of L-carnitine on oxidant/antioxidant status in acetic acid-induced colitis. Dig Dis Sci 2006;51:488-94. [CrossRef]

15. Tufekci O, Gunes D, Ozogul C, Kolatan E, Altun Z, Yilmaz O, et al. Evaluation of the effect of acetyl L-carnitine on experimental cisplatin nephrotoxicity. Chemotherapy 2009;55:451-9. [CrossRef]

16. Gunes D, Kirkim G, Kolatan E, Guneri EA, Ozogul C, Altun Z, et al. Evaluation of the effect of acetyl L-carnitine on experimental cisplatin ototoxicity and neurotoxicity. Chemotherapy 2011;57:186-94. [CrossRef]

17. Calò LA, Pagnin E, Davis PA, Semplicini A, Nicolai R, Calvani M, et al. Antioxidant effect of $L$-carnitine and its short chain esters: relevance for the protection from oxidative stress related cardiovascular damage. Int J Cardiol 2006;107:54-60. [CrossRef]

18. Ng CM, Blackman MR, Wang C, Swerdloff RS. The role of carnitine in the male reproductive system. Ann N Y Acad Sci 2004;1033:177-88. [CrossRef]

19. Jeulin C, Lewin LM. Role of free L-carnitin and acetyl-L-carnitine in post-gonadal maturation of mammalian spermatozoa. Hum Reprod Update 1996;2:87-102. [CrossRef]

20. Yeste M, Sancho S, Briz M, Pinart E, Bussalleu E, Bonet S. A diet supplemented with L-carnitine improves the sperm quality of Pietrain but not of Duroc and Large White boars when photoperiod and temperature increase. Theriogenology 2010;73:577-86. [CrossRef]

21. Gonzalez VM, Fuertes MA, Alonso C, Perez JM. Is cisplatin-induced cell death always produced by apoptosis? Mol Pharmacol 2001;59:657-63. 
22. Deavall DG, Martin EA, Horner JM, Roberts R. Drug-induced oxidative stress and toxicity. J Toxicol 2012;2012:645460.

23. Marcon L, Zhang $X$, Hales BF, Robaire B, Nagano MC. Effects of chemotherapeutic agents for testicular cancer on rat spermatogonial stem/progenitor cells. J Androl 2011;32:432-43. [CrossRef]

24. Topcu-Tarladacalisir Y, Kanter M, Uzal MC. Role of L-carnitine in the prevention of seminiferous tubules damage induced by gamma radiation: a light and electron microscopic study. Arch Toxicol 2009;83:735-46. [CrossRef]

25. Ward MA. Intracytoplasmic sperm injection effects in infertile azh mutant mice. Biol Reprod 2005;73:193-200. [CrossRef]
26. Favareto AP, Fernandez CD, da Silva DA, Anselmo-Franci JA, Kempinas Wde G. Persistent impairment of testicular histology and sperm motility in adult rats treated with cisplatin at peri-puberty. Basic Clin Pharmacol Toxicol 2011;109:85-96. [CrossRef]

27. Ateşşahin A, Sahna E, Türk G, Ceribaşi AO, Yilmaz S, Yüce A, et al. Chemoprotective effect of melatonin against cisplatin-induced testicular toxicity in rats. J Pineal Res 2006;41:21-7. [CrossRef]

28. Lirdi LC, Stumpp T, Sasso-Cerri E, Miraglia SM. Amifostin protective effect on cisplatin-treated rat testis. Anat Rec (Hoboken) 2008;291:797-808. [CrossRef] 